\title{
PENGEMBANGAN TES DIAGNOSTIK MATA PELAJARAN IPA SMP
}

Mujiman Hendri Wijaya, Suratno, Aminuddin HP

Program Pascasarjana Universitas Lambung Mangkurat

Jl. Brigjen. H. Hasan Basri, Kotak Pos 219, Banjarmasin 70123

muji.wnry@yahoo.com, ontar_ria@yahoo.com, aminuddinpatra@gmail.com

\begin{abstract}
Abstrak
Penelitian ini bertujuan mengembangkan tes diagnostik pada materi mata pelajaran IPA SMP. Tahapan penelitian meliputi penyusunan tes dan penentuan penggunaan acuan kriteria atau norma, serta analisis validitas dan reliabilitas. Penyusunan tes meliputi (1) penentuan tujuan; (2) penyusunan kisi-kisi; (3) penulisan butir soal; (4) telaah soal diikuti revisi; (5) uji coba soal; (6) analisis dan interpretasi; (7) perakitan soal; (8) implementasi/uji coba. Berdasarkan kriteria validitas isi dan konstruk diperolah 29 butir soal yang baik, dengan indeks reliabilitas sebesar 0,814. Distribusi capaian hasil belajar menunjukkan bahwa sebanyak 14,67\% siswa mendapat skor penguasaan di atas 65\%, dan 85,33\% siswa memperoleh skor penguasaan di bawah $65 \%$. Lebih rinci capaian hasil belajar pada dimensi pengetahuan faktual 53,87\%; konseptual 51,40\%; prosedural 49,87\%; metakognitif 49,80\%; dengan rata-rata $51,23 \%$. Jika acuan batas pencapaian 65\% maka penguasaan siswa masih berada di bawah batas pencapaian minimal dan mengalami kesulitan belajar.
\end{abstract}

Kata kunci: tes diagnostik, IPA SMP, dimensi pengetabuan 


\title{
DEVELOPING DIAGNOSTIC TESTS FOR THE NATURAL SCIENCE SUBJECT IN JUNIOR HIGH SCHOOL
}

\author{
Mujiman Hendri Wijaya, Suratno, Aminuddin HP \\ Program Pascasarjana Universitas Lambung Mangkurat \\ Jl. Brigjen. H. Hasan Basri, Kotak Pos 219, Banjarmasin 70123 \\ muji.wnry@yahoo.com ontar_ria@yahoo.com \\ aminuddinpatra@gmail.com
}

\begin{abstract}
This study aims to develop a diagnostic test on the natural science subject in junior high school. The stages of the study include the preparation of the test and the determination of the use of reference criteria or norms, as well as the validity and reliability analysis. Preparation of the test includes: (1) setting goals, (2) the preparing the blue print test, (3) writing about the items, (4) analyzing and revising the test (5) trying out the test, (6) analyzing and interpreting the test, (7) assembling the problem, (8) implementing or testing. Based on the criteria of content and constructs validity 29 items were obtained, with a reliability index of 0.814 . Distribution achievement of learning outcomes shows that $14.67 \%$ of students got mastery over $65 \%$, and $85.33 \%$ of students got mastery below $65 \%$. In more details, the learners' achievement of factual knowledge was: $53.87 \%$; conceptual: $51.40 \%$; procedural: 49.87\%; metacognitive: $49.80 \%$, with average: $51.23 \%$. If the passing grade for achievement is 65\%; then students' mastery is still below the minimum achievement and they have learning difficulties.
\end{abstract}

Keywords: diagnostic tests, science subject, dimensions of knowledge 


\section{Pendahuluan}

Meningkatnya partisipasi pendidikan belum sepenuhnya diikuti dengan sistem evaluasi pendidikan yang terpercaya. Indikatornya adalah belum digunakannya hasil ujian nasional pendidikan menengah untuk melanjutkan ke pendidikan tinggi karena adanya penyimpangan dalam pelaksanaan ujian nasional, dan substansi ujian nasional belum mengukur pencapaian hasil belajar peserta didik yang sebenarnya serta belum terpadunya hasil ujian nasional dengan ujian masuk perguruan tinggi (Kemendiknas, 2010: 46).

Berdasarkan Peraturan Pemerintah Nomor 19 Tahun 2005 Pasal 63 bahwa penilaian hasil belajar dilakukan oleh pendidik, satuan pendidikan, dan oleh pemerintah. Penilaian hasil belajar oleh pendidik dilakukan secara berkesinambungan untuk memantau proses, kemajuan, dan perbaikan hasil dalam bentuk ulangan harian, ulangan tengah semester, ulangan akhir semester, dan ulangan kenaikan kelas. Penilaian pendidik digunakan untuk menilai pencapaian kompetensi peserta didik, bahan penyusunan laporan kemajuan hasil belajar, dan memperbaiki proses pembelajaran.

Penilaian hasil belajar oleh satuan pendidikan bertujuan menilai pencapaian standar kompetensi lulusan untuk semua mata pelajaran, sedangkan penilaian hasil belajar oleh pemerintah bertujuan untuk menilai pencapaian kompetensi lulusan secara nasional pada mata pelajaran tertentu dalam kelompok mata pelajaran ilmu pengetahuan dan teknologi dan dilakukan dalam bentuk ujian nasional (Kemendiknas, 2010: 1). Hasil ujian nasional digunakan sebagai satu faktor penentu kelulusan peserta didik dari satuan pendidikan dengan ketentuan bobot nilai $40 \%$ dari nilai sekolah dari mata pelajaran yang diujikan dan 60\% untuk nilai ujian nasional (BSNP, 2012: 24).

Laporan Kementerian Pendidikan Nasional Badan Penelitian dan Pengembangan Pendidikan selama tiga tahun terakhir menjelaskan daya serap siswa terhadap Kompetensi Dasar Mata Pelajaran IPA yang diujikan dalam ujian nasional di Kabupaten Barito Kuala rata-rata adalah 23,58\% rendah, 10,82\% sedang dan 65,55\% tinggi (BNSP, 2010). Data ini menunjukkan adanya ketidakwajaran terhadap daya serap yang dicapai oleh 
siswa. Ketidakwajaran ini menunjukkan bahwa masih ada siswa yang mengalami kesulitan dalam menguasai materi pelajaran yang diujikan pada ujian nasional, untuk menelusuri kesulitan tersebut dapat menggunakan tes diagnostik.

Tujuan tes diagnostik adalah untuk mengidentifikasi siswa yang mengalami masalah dalam belajar (Wright, 2008: 227). Tes diagnostik dapat dilakukan terhadap calon siswa baru sebagai input, terhadap siswa yang baru yang sudah mulai mengikuti program belajar, terhadap siswa yang sedang mengikuti program belajar dan pada waktu siswa akan mengakhiri program belajar. Kekhususan tes diagnostik dibanding tes lain adalah tes diagnostik dapat digunakan untuk mengatasi kesulitan belajar (Mukhan, 2011:1). Berdasarkan uraian tersebut perlu dikembangkan tes diagnostik yang dapat mengungkap kesulitan belajar siswa pada materi pelajaran IPA.

Istilah pengembangan dalam penelitian ini adalah suatu proses yang dipakai untuk mengembangkan dan memvalidasi produk pendidikan (Styosari, 2012: 230). Tes diagnostik adalah tes yang digunakan untuk mengetahui kelemahan-kelemahan siswa sehingga berdasarkan kelemahankelemahan tersebut dapat dilakukan penempatan (placement) yang tepat (Arikunto, 2009: 34). Instrumen tes diagnostik dalam penelitian ini adalah produk hasil pengembangan yang telah divalidasi dan diketahui reliabilitasnya. Instrumen tes ini dilengkapi dengan manual tes dan dapat digunakan pada siswa yang duduk di kelas IX awal atau semester ganjil. Kesulitan belajar yang dimaksud dalam penelitian ini adalah suatu kondisi dalam suatu proses belajar yang ditandai adanya hambatan-hambatan tertentu untuk mencapai hasil belajar (Mulyadi, 2010: 6). Indikator adanya kesulitan belajar siswa dalam penelitian ini ditunjukkan oleh skor perolehan hasil tes diagnostik yang belum mencapai di atas $65 \%$. Hasil belajar dalam penelitian ini adalah hasil belajar pada dimensi pengetahuan yaitu dimensi faktual, konseptual, prosedural dan metakognitif.

Terkait dengan hal tersebut, tujuan penelitian ini adalah untuk mengembangkan tes diagnostik pada materi mata pelajaran IPA SMP. 


\section{Metode Penelitian}

Penelitian ini termasuk penelitian pengembangan, yaitu pengembangan tes diagnostik. Penelitian dilaksanakan dalam beberapa tahap, yaitu (1) penyusunan tes diagnostik; (2) penentuan acuan norma/acuan kriteria tes; (3) reliabilitas tes diagnostik; (4) pembuktian validitas tes diagnostik; (5) revisi tes diagnostik; (6) estimasi reliabilitas tes diagnostik yang telah direvisi; (7) pembuktian validitas tes diagnostik yang telah direvisi (Sudirgo Wibowo, 1977: 42). Langkah-langkah dalam penyusunan tes diagnostik ini meliputi (1) penentuan tujuan tes; (2) penyusunan kisi-kisi tes; (3) penulisan butir soal; (4) penelaahan soal (review) dan revisi soal; (5) uji coba soal; (6) analisis dan interpretasi; (7) perakitan butir soal menjadi perangkat tes; (8) implementasi tes diagnostik (Mukhan, 2011:1).

Acuan penilaian dalam pelaksanaan tes diagnostik ini adalah acuan patokan atau acuan kriteria (criterion-referenced) dan acuan norma (norm reference). Acuan penilaian patokan digunakan untuk menentukan kriteria tertentu yaitu klasifikasi "belum tuntas" atau "tuntas" sehingga dapat mengikuti kegiatan pembelajaran berikutnya (Depdiknas, 2007: 13). Acuan kriteria digunakan saat penentuan nilai ulangan formatif, siswa yang belum menguasai materi pelajaran atau mendapat nilai di bawah kriteria ketuntasan minimal (KKM) berarti tidak tuntas. Batas kriteria (criterionreferenced) atau KKM yang ideal adalah 75\% (Depdiknas, 2010a: 21). Siswa yang belum mampu mencapai KKM selanjutnya dapat mengikuti tes diagnostik untuk mengetahui apakah siswa termasuk dalam kelompok yang mengalami kesulitan belajar.

Penentuan siswa dalam kelompok yang mengalami kesulitan atau tidak dilakukan dengan menggunakan penilaian acuan norma. Kelompok siswa yang mengalami kesulitan belajar adalah kelompok siswa yang memiliki pencapaian tujuan belajar di bawah dari 0,25 standar deviasi di atas rata-rata (Mulyadi, 2010: 13). Siswa yang dikatakan mengalami kesulitan belajar adalah mereka yang mempunyai nilai di bawah $65+0,25 \times$ standar deviasi atau siswa yang memperoleh skor di bawah mean $+0,25 \mathrm{x}$ standar deviasi. Tingkat kesukaran tes diagnostik adalah sedang atau 65\% batas minimal pencapaian siswa. 
Reliabilitas tes diestimasi dengan menggunakan rumus Cronbach's Alpha. Analisis secara keseluruhan menggunakan perangkat lunak SPSS 15.0 for windows. Hasil analisis statistik selanjutnya dibandingkan dengan nilai Alpha. Ghozali (2007: 42) mengemukakan bahwa uji statistik Cronbach's Apha reliabel jika mempunyai nilai Alpha $>0,60$. Membuktikan validitas tes diagnostik dilakukan dengan menganalisis validitas logis dan validitas empiris. Analisis validitas logis yaitu meliputi isi dan konstruk butir soal yang ditelaah oleh tiga orang ahli dibidangnya.

Instrumen tes yang telah diujicobakan direvisi kembali untuk mendapatkan sebuah instrumen tes diagnostik yang baik. Revisi soal tes meliputi (a) taraf kesukaran butir tes dengan klasifikasi: soal sukar mempunyai indeks kesukaran 0,00-0,30, soal sedang mempunyai indeks kesukaran 0,31-0,70; dan soal mudah mempunyai indeks kesukaran 0,711,00 (Wahidmurni, 2010: 132), taraf kesukaran untuk tes diagnostik adalah sedang $(0,65)$; (b) daya pembeda butir soal dengan klasifikasi soal tidak dipakai/dibuang mempunyai daya beda 0,00-0,19, soal diperbaiki mempunyai daya beda 0,20-0,29, soal diterima tetapi perlu diperbaiki mempunyai daya beda 0,30-0,39, soal diterima baik sekali (excellent) mempunyai daya beda 0,40-1,00 (Wahidmurni, 2010: 136); (c) distribusi pilihan jawaban (efektivitas distraktor), distraktor dapat berfungsi jika paling sedikit dipilih oleh 5\% peserta tes (Arikunto, 2009: 220).

Sampel dalam penelitian ini adalah butir-butir tes diagnostik. Butir tes diagnostik disusun dan dikembangkan berdasarkan SK dan KD pada mata pelajaran IPA Biologi SMP. Penentuan sampel dilakukan dengan cara sampel kuota (quota sample). Banyaknya sampel adalah $5 \mathrm{SK}$ dan $20 \mathrm{KD}$ mata pelajaran IPA Biologi SMP. Sampel dikembangkan menjadi 40 butir soal pilihan ganda dengan empat alternatif jawaban. Responden penelitian ini adalah siswa SMPN kelas VIII tahun pelajaran 2011/2012, sebanyak 150 siswa.

Penelitian ini dilaksanakan di SMP Negeri di wilayah Kabupaten Barito Kuala Provinsi Kalimantan Selatan dimulai sejak bulan April sampai Juni tahun 2012. Data yang diperoleh dari masing-masing responden dianalisis dalam dua bagian, yaitu analisis butir soal dan analisis hasil penelitian. Analisis data butir soal dilakukan dengan perangkat lunak SPSS 
15.0 for windows, yaitu validitas isi, reliabilitas, tingkat kesukaran, daya beda dan efektivitas distraktor. Analisis pada lembar kerja siswa dilakukan untuk mengetahui dan merekam jenis kesalahan (type error) yang ada dalam respon siswa. Kegiatan yang dilakukan adalah menganalisis deskripsi jawaban siswa.

\section{Hasil Penelitian dan Pembahasan}

Telaah dan revisi butir soal sebelum uji coba menghasilkan 2 kategori, yaitu diterima tanpa revisi atau diterima dengan revisi. Hasil telaah butir soal pada aspek materi, konstruksi, dan bahasa menghasilkan 14 butir soal tanpa revisi dan 26 butir soal diterima dengan revisi disajikan pada Tabel 1.

Tabel 1. Hasil Telaah Butir Soal yang Memerlukan Revisi

\begin{tabular}{|c|c|c|c|}
\hline Domain & No & Kriteria & Nomor Soal \\
\hline \multirow[t]{3}{*}{ materi } & 1 & kesesuaian soal dengan indikator & $4,10,11,13,24,30,37$ \\
\hline & 2 & $\begin{array}{l}\text { isi materi sesuai dengan tujuan } \\
\text { pengukuran }\end{array}$ & $\begin{array}{l}4,10,13,14,15,16,18 \\
21,24,29,34,37,38\end{array}$ \\
\hline & 3 & $\begin{array}{l}\text { pilihan/jawaban benar-benar } \\
\text { berfungsi }\end{array}$ & 2,8 \\
\hline \multirow[t]{4}{*}{ konstruksi } & 4 & $\begin{array}{l}\text { Pokok soal (stem) dirumuskan } \\
\text { dengan jelas }\end{array}$ & $2,11,13,22,29,33,35$ \\
\hline & 5 & $\begin{array}{l}\text { Rumusan soal dan pilihan } \\
\text { dirumuskan dengan tegas }\end{array}$ & $2,11,13,20,26,29,35$ \\
\hline & 6 & Pilihan jawaban homogen & 3 \\
\hline & 7 & $\begin{array}{l}\text { Wacana, gambar, atau grafik benar- } \\
\text { benar berfungsi }\end{array}$ & $11,13,18,20,28,29$ \\
\hline \multirow[t]{2}{*}{ bahasa } & 8 & $\begin{array}{l}\text { Setiap soal harus menggunakan } \\
\text { bahasa sesuai kaidah EYD }\end{array}$ & $7,9,12,29$ \\
\hline & 9 & $\begin{array}{l}\text { Menggunakan bahasa yang } \\
\text { komunikatif, agar mudah dimengerti. }\end{array}$ & 1 \\
\hline
\end{tabular}

Pengembangan Tes Diagnostik, Mata Pelajaran IPA SMP - 25

Mujiman Hendri Wijaya, Suratno, Aminuddin HP 
Berdasarkan data hasil analisis kualitatif butir soal, dapat disimpulkan bahwa jumlah butir soal yang diterima tanpa revisi sebanyak 35\% dan butir soal yang diterima dengan revisi sebanyak 65\%. Hasil telaah menunjukkan bahwa kekeliruan pada domain materi sebanyak 18 soal atau 45\%, pada domain konstruksi 12 soal atau 30\%, dan pada domain bahasa 5 soal atau $13 \%$. Hasil telaah butir soal ini menjadi dasar untuk perbaikan butir soal sebelum diujicobakan.

Butir soal yang telah direvisi pada domain materi, konstruksi dan bahasa, dilakukan ujicoba soal kepada responden. Tingkat kesukaran butir soal pada ujicoba ke-1 dan ke-2 menunjukkan hasil seperti pada Tabel 2.

Tabel 2. Tingkat kesukaran soal pada uji ke-1 dan ke-2

\begin{tabular}{cccccccccccccccccccccc}
\hline \multicolumn{2}{c}{ Nomor Soal } & 1 & 2 & 3 & 4 & 5 & 6 & 7 & 8 & 9 & 10 & 11 & 12 & 13 & 14 & 15 & 16 & 17 & 18 & 19 & 20 \\
\hline \multirow{3}{*}{$\begin{array}{c}\text { Jumlah betul } \\
\end{array}$} & Uji ke-1 & 24 & 9 & 9 & 13 & 17 & 6 & 21 & 15 & 25 & 6 & 6 & 8 & 24 & 24 & 11 & 25 & 18 & 15 & 25 & 20 \\
& Uji ke-2 & 76 & 66 & 69 & 56 & 111 & 44 & 65 & 56 & 73 & 53 & 53 & 34 & 36 & 64 & 59 & 45 & 92 & 101 & 66 & 61 \\
\multirow{2}{\text{IK}}{} & Uji ke-1 & 0,92 & 0,35 & 0,35 & 0,50 & 0,65 & 0,23 & 0,81 & 0,58 & 0,96 & 0,23 & 0,23 & 0,31 & 0,92 & 0,92 & 0,42 & 0,96 & 0,69 & 0,58 & 0,96 & 0,77 \\
(proporsi) & Uji ke-2 & 0,51 & 0,44 & 0,46 & 0,37 & 0,74 & 0,29 & 0,43 & 0,37 & 0,49 & 0,35 & 0,35 & 0,23 & 0,24 & 0,43 & 0,39 & 0,30 & 0,61 & 0,67 & 0,44 & 0,41
\end{tabular}

Lanjutan

\begin{tabular}{cccccccccccccccccccccc}
\hline \multicolumn{2}{c}{ Nomor Soal } & 21 & 22 & 23 & 24 & 25 & 26 & 27 & 28 & 29 & 30 & 31 & 32 & 33 & 34 & 35 & 36 & 37 & 38 & 39 & 40 \\
\hline \multirow{3}{*}{$\begin{array}{c}\text { Jumlah betul } \\
\end{array}$} & Uji ke-1 & 11 & 22 & 25 & 25 & 13 & 5 & 11 & 17 & 11 & 9 & 5 & 8 & 10 & 13 & 11 & 15 & 8 & 9 & 7 & 10 \\
& Uji ke-2 & 65 & 106 & 46 & 70 & 102 & 59 & 69 & 78 & 53 & 62 & 39 & 50 & 43 & 73 & 81 & 61 & 50 & 66 & 55 & 45 \\
\multirow{2}{*}{$\begin{array}{c}\text { IK } \\
\text { (proporsi) }\end{array}$} & Uji ke-1 & 0,42 & 0,85 & 0,96 & 0,96 & 0,50 & 0,19 & 0,42 & 0,65 & 0,42 & 0,35 & 0,19 & 0,31 & 0,38 & 0,50 & 0,42 & 0,58 & 0,31 & 0,35 & 0,27 & 0,38 \\
& Uji ke-2 & 0,43 & 0,71 & 0,31 & 0,47 & 0,68 & 0,39 & 0,46 & 0,52 & 0,35 & 0,41 & 0,26 & 0,33 & 0,29 & 0,49 & 0,54 & 0,41 & 0,33 & 0,44 & 0,37 & 0,30
\end{tabular}

Keterangan: IK = Indeks Kesukaran

Tafsiran taraf kesukaran butir tes diklasifikasikan sebagai berikut: soal sukar mempunyai indeks $0,00-0,30$, soal sedang mempunyai indeks 0,31-0,70. Soal mudah mempunyai indeks 0,71-1,00 (Wahidmurni, 2010:132), taraf kesukaran untuk tes diagnostik adalah sedang. Uji coba soal ke-1 menghasilkan $15,00 \%$ soal yang dikategorikan sukar, kategori sedang se-banyak 57,50\%, dan kategori mudah sebanyak 27,50\%. Ujicoba ke-2 meng-hasilkan soal dengan kategori sukar sebanyak $17,50 \%$, kategori sedang sebanyak $77,50 \%$, dan kategori mudah sebanyak 5,00 \%. 
Analisis daya beda butir soal pada uji coba ke-1 dan ke-2 menghasilkan soal dengan indeks daya beda butir soal disajikan pada Tabel 3 .

Tabel 3. Data daya beda pada uji coba ke-1 dan uji coba ke-2

\begin{tabular}{|c|c|c|c|c|c|c|c|c|c|c|c|c|c|c|c|c|c|c|c|c|c|}
\hline \multicolumn{2}{|c|}{ Nomor soal } & 1 & 2 & 3 & 4 & 5 & 6 & 7 & 8 & 9 & 10 & 11 & 12 & 13 & 14 & 15 & 16 & 17 & 18 & 19 & 20 \\
\hline \multirow{3}{*}{$\begin{array}{l}\text { Indeks } \\
\text { daya } \\
\text { beda }\end{array}$} & Uji ke-1 & 0,00 & 0,44 & 0,44 & 0,40 & 0,40 & 0,500 & 0,10 & 0,100 & 0,100 & 0,300 & 0,500 & 0,500 & 0,000 & 0,000 & 0,500 & 0,30 & 0,100 & 0,400 & 0,100 & 0,30 \\
\hline & Uji ke-2 & 0,33 & 0,40 & 0,43 & 0,43 & 0,25 & 0,400 & $0,43 \mathrm{c}$ & 0,330 & 0,550 & 0,400 & 0,400 & 0,400 & 0,330 & 0,400 & 0,700 & 0,450 & 0,450 & 0,400 & 0,300 & 0,20 \\
\hline & \multicolumn{21}{|c|}{ Lanjutan } \\
\hline \multicolumn{2}{|c|}{ Nomor soal } & 21 & 22 & 23 & 24 & 25 & 26 & 27 & 28 & 29 & 30 & 31 & 32 & 33 & 34 & 35 & 36 & 37 & 38 & 39 & 40 \\
\hline \multirow{2}{*}{$\begin{array}{l}\text { Indeks } \\
\text { daya } \\
\text { beda }\end{array}$} & Uji ke-1 & 0,40 & 0,00 & 0,10 & $0,10 \mathrm{c}$ & 0,40 & 0,400 & 0,40 & 0,500 & 0,400 & 0.400 & 0,400 & 0,500 & 0,500 & 0,400 & 0,400 & 0,400 & 0,300 & 0,400 & & 0,50 \\
\hline & ji ke-2 & & 0,25 & 0,35 & $0,48 \mathrm{c}$ & 0,40 & 0,400 & 0,40 & 0,480 & 0,430 & 0,400 & 0,430 & 0,580 & 0,400 & 0,500 & 0,450 & 0,380 & 0,450 & 0,400 & 0,450 & 0,48 \\
\hline
\end{tabular}

Uji coba ke-1 menghasilkan soal dengan klasifikasi sebagai berikut (a) soal yang tidak dipakai sebanyak 30,00\%; (b) soal dengan klasifikasi diterima dengan diperbaiki sebanyak 7,50\%; (c) soal dengan klasifikasi diterima dengan baik sebanyak $7,50 \%$. Uji coba ke- 2 menghasilkan butir soal yang memiliki daya beda dengan kategori soal diperbaiki $7,50 \%$, diterima dengan perbaikan $15,00 \%$, diterima dengan baik $77,50 \%$.

Tafsiran distribusi pilihan jawaban (efektivitas distraktor) dapat berfungsi jika paling sedikit dipilih oleh 5\% peserta tes (Arikunto, 2009:220). Efektivitas pengecoh hasil uji coba ke-1 pada option A terdapat 12 option di bawah 5\%. Option A yang efektivitasnya sama dengan atau lebih dari 5\% terdapat sebanyak 28 option. Efektivitas option B yang di bawah 5\% terdapat 8 option B yang efektivitasnya sama dengan atau lebih dari $5 \%$ terdapat sebanyak 32 option. Efektivitas option C yang di bawah 5\% terdapat 9 option. Option $\mathrm{C}$ yang efektivitasnya sama dengan atau lebih dari 5\% terdapat sebanyak 31 option. Efektivitas option D yang di bawah 5\% terdapat 9 option. Option D yang efektivitasnya sama dengan atau lebih dari $5 \%$ terdapat sebanyak 31 option.

Analisis efektivitas pengecoh pada uji coba ke-1 dan ke-2 menghasilkan butir soal dengan efektivitas pengecoh pada option soal disajikan pada Tabel 4. 
Tabel 4. Efektivitas Pengecoh pada Uji Coba Ke-1 dan Ke-2

\begin{tabular}{|c|c|c|c|c|c|c|c|c|c|c|c|c|c|c|c|c|c|c|c|c|c|c|}
\hline \multirow{9}{*}{$\begin{array}{c}\text { Kunci dan } \\
\text { persentase } \\
\text { option } \\
\text { jawaban } \\
(\%)\end{array}$} & \multicolumn{2}{|c|}{ No.soal } & 1 & 2 & 3 & 4 & 5 & 6 & 7 & 8 & 9 & 10 & 11 & 12 & 13 & 14 & 15 & 16 & 17 & 18 & 19 & 20 \\
\hline & \multirow[b]{2}{*}{ 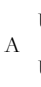 } & Uji-1 & 3,85 & 11,54 & 23,08 & 15,38 & 65,38 & 19,23 & 3,85 & 38,46 & 0,00 & 57,69 & 23,08 & 30,77 & 3,85 & 3,85 & 34,62 & 3,85 & 0,00 & 15,38 & 3,85 & 76,92 \\
\hline & & Uji-2 & 1,30 & 16,00 & 7,30 & 25,30 & 79,30 & 8,70 & 10,70 & 12,00 & 14,70 & 52,00 & 6,70 & 22,70 & 10,70 & 21,30 & 43,30 & 40,00 & 6,70 & 10,00 & 18,00 & 40,70 \\
\hline & \multirow{2}{*}{ B } & Uji-1 & 92,31 & 26,92 & 15,38 & 19,23 & 11,54 & 23,08 & 80,77 & 7,69 & 0,00 & 23,08 & 26,92 & 34,62 & 0,00 & 3,85 & 11,54 & 3,85 & 23,08 & 11,54 & 96,15 & 0,00 \\
\hline & & $\mathrm{Uji}-2$ & 50,70 & 26,70 & 21,30 & 24,00 & 6,70 & 41,30 & 42,70 & 29,30 & 12,70 & 30,00 & 12,70 & 50,70 & 40,70 & 29,30 & 7,30 & 18,70 & 24,70 & 9,30 & 50,70 & 46,00 \\
\hline & \multirow{2}{*}{ c } & Uji-1 & 0,00 & 19,23 & 34,62 & 50,00 & 7,69 & 15,38 & 15,38 & 3,85 & 96,15 & 7,69 & 23,08 & 3,85 & 3,85 & 0,00 & 42,31 & 0,00 & 69,23 & 57,69 & 0,00 & 11,54 \\
\hline & & Uji-2 & 19,30 & 12,70 & 56,70 & 37,30 & 6.00 & 6,70 & 26,70 & 23,30 & 48,70 & 10,00 & 31,30 & 12,70 & 24,70 & 6,70 & 39,30 & 6,00 & 61,30 & 67,30 & 9,30 & 6,00 \\
\hline & \multirow{2}{*}{$\mathrm{D}$} & Uji-1 & 0,00 & 34,62 & 23,08 & 15,38 & 15,38 & 42,31 & 0,00 & 50,00 & 3,69 & 7,69 & 23,08 & 19,23 & 92,31 & 92,31 & 11,54 & 96,15 & 7,69 & 15,38 & 0,00 & 3,85 \\
\hline & & Uji-2 & 12,70 & 44,00 & 7,30 & 13,30 & 8,00 & 44,00 & 20,00 & 35,30 & 22,70 & 8,00 & 45,30 & 14,00 & 24,00 & 42,70 & 10,00 & 10,70 & 7,30 & 13,30 & 14,70 & 7,30 \\
\hline \multicolumn{23}{|c|}{ Lanjutan } \\
\hline \multirow{9}{*}{$\begin{array}{c}\text { Kunci dan } \\
\text { persentase } \\
\text { option } \\
\text { jawaban } \\
(\%)\end{array}$} & \multicolumn{2}{|c|}{ No.soal } & 21 & 22 & 23 & 24 & 25 & 26 & 27 & 28 & 29 & 30 & 31 & 32 & 33 & 34 & 35 & 36 & 37 & 38 & 39 & 40 \\
\hline & & Uji-1 & 19,23 & 0,00 & 0,00 & 0,00 & 50,00 & 3,38 & 11,54 & 7,69 & 19,23 & 23,08 & 38,46 & 11,54 & 15,38 & 15,38 & 42,31 & 7,69 & 42,31 & 11,54 & 26,92 & 38,46 \\
\hline & & $\mathrm{Uji}_{\mathrm{j}-2}$ & 30,0 & 6,70 & 31,30 & 8,00 & 68,00 & 10,70 & 8,70 & 7,30 & 26,00 & 25,30 & 24,00 & 12,70 & 34,70 & 15,30 & 67,40 & 14,70 & 42,00 & 17,30 & 36,70 & 32,00 \\
\hline & \multirow{2}{*}{ B } & Uji-1 & 15,38 & 15,38 & 0,00 & 0,00 & 11,54 & 38,46 & 42,31 & 11,54 & 42,31 & 19,23 & 23,08 & 50,00 & 11,54 & 11,54 & 30,77 & 3,85 & 11,54 & 34,62 & 19,23 & 38,46 \\
\hline & & Uji-2 & 18.0 & 12,70 & 8,70 & 36,70 & 10,00 & 18,00 & 46,00 & 31,30 & 35,30 & 22,70 & 20,00 & 42,00 & 16,00 & 16,70 & 20,00 & 6,00 & 10,70 & 44,00 & 16,00 & 30,00 \\
\hline & \multirow{2}{*}{ 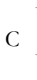 } & Uji-1 & 19,23 & 84,62 & 96,15 & 0,00 & 15,38 & 19,23 & 7,69 & 19,23 & 15,38 & 34,62 & 19,23 & 30,77 & 26,92 & 50,00 & 19,23 & 26,92 & 30,77 & 26,92 & 23,08 & 19,23 \\
\hline & & $\mathrm{Uji}-2$ & 8,0 & 70,70 & 31,30 & 8,70 & 10,70 & 17,30 & 17,30 & 9,30 & 26,70 & 41,30 & 20,70 & 33,30 & 20,70 & 48,70 & 7,30 & 34,70 & 33,30 & 21,30 & 24,00 & 29,30 \\
\hline & \multirow{2}{*}{$\mathrm{D}$} & Uji-1 & 42,31 & 0,00 & 0,00 & 96,15 & 15,38 & 38,46 & 30,77 & 61,54 & 19,23 & 15,38 & 11,54 & 3,85 & 38,46 & 23,08 & 3,85 & 57,69 & 15,38 & 23,08 & 30,77 & 7,69 \\
\hline & & $\mathrm{Uji}-2$ & 43,3 & 10,00 & 23,30 & 46,70 & 11,30 & 24,00 & 28,00 & 52,00 & 12,00 & 10,70 & 6,70 & 12,00 & 28,70 & 18,70 & 5,30 & 48,70 & 14,70 & 16,70 & 23,30 & 8,70 \\
\hline
\end{tabular}

Efektivitas pengecoh butir soal pada uji coba ke-1 yang belum dapat mempengaruhi responden sampai 5\% diperbaiki dan diujicobakan kembali. Uji coba ke-2 menghasilkan butir soal dengan efektivitas pengecoh lebih dari $5 \%$.

Reliabilitas soal dianalisis menggunakan perangkat lunak SPSS 15.0. for Windows. Reliabilitas soal pada uji ke-1 dan uji coba ke-2 menghasilkan butir soal seperti pada Tabel 5 .

Tabel 5. Data Statistik Reliabilitas Soal Tes Diagnostik

\begin{tabular}{cccc}
\hline \multicolumn{2}{c}{ Uji coba ke-1 } & \multicolumn{2}{c}{ Uji coba ke-1 } \\
\hline Reliability Statistics & Nof Items & Reliability Statistics & N of Items \\
Cronbach's Alpha & 40 & 0,8143 & 40 \\
0,864 & 40 . & 0 & \\
\hline
\end{tabular}


Hasil analisis statistik dengan menggunakan perangkat lunak SPSS 15.0. for Windows pada uji ke-1 adalah 0,864 sedangkan pada uji ke-2 adalah 0,814. Ghozali (2007: 42) mengemukakan bahwa uji statistik Cronbach's Apha reliabel jika nilai Alpha $>$ 0,60. Uji statistik ke-1 dan ke-2 menghasilkan nilai Alpha di atas 0,60, dengan demikian konstruk tes diagnostik yang dikembangkan adalah reliabel.

Hasil analisis tentang tes penguasaan belajar pada butir soal yang mengukur aspek kognitif disajikan dalam Tabel 6.

Tabel 6. Data Tingkat Pencapaian Berdasarkan Aspek Kognitif

\begin{tabular}{|c|c|c|c|c|c|c|c|}
\hline \multirow[t]{2}{*}{ Aspek kognitif } & \multicolumn{3}{|c|}{ No. Jumlah Persentase } & \multicolumn{4}{|c|}{ No. Jumlah Persentase Rata- } \\
\hline & Soal & Betul & benar & Soal & Betul & benar & rata \\
\hline \multirow{6}{*}{$\begin{array}{l}\text { Pengetahuan } \\
\text { (C1) }\end{array}$} & 3 & 69 & $46,00 \%$ & 16 & 45 & $30,00 \%$ & \multirow[t]{6}{*}{$39,22 \%$} \\
\hline & 6 & 44 & $29,33 \%$ & 19 & 66 & $44,00 \%$ & \\
\hline & 7 & 65 & $43,33 \%$ & 25 & 102 & $68,00 \%$ & \\
\hline & 11 & 53 & $35,33 \%$ & 26 & 59 & $39,33 \%$ & \\
\hline & 13 & 36 & $24,00 \%$ & 27 & 69 & $46,00 \%$ & \\
\hline & 15 & 59 & $39,33 \%$ & 31 & 39 & $26,00 \%$ & \\
\hline \multirow{4}{*}{$\begin{array}{l}\text { Pemahaman } \\
\text { (C2) }\end{array}$} & 8 & 56 & $37,33 \%$ & 33 & 43 & $28,67 \%$ & \multirow{4}{*}{$\begin{array}{l}41,14 \\
\%\end{array}$} \\
\hline & 21 & 65 & $43,33 \%$ & 36 & 61 & $40,67 \%$ & \\
\hline & 22 & 106 & $70,67 \%$ & 39 & 55 & $36,67 \%$ & \\
\hline & 23 & 46 & $30,67 \%$ & & & & \\
\hline \multirow[t]{5}{*}{ Penerapan (C3) } & 1 & 76 & $50,67 \%$ & 24 & 70 & $46,67 \%$ & \multirow{5}{*}{$\begin{array}{l}42,60 \\
\%\end{array}$} \\
\hline & 2 & 66 & $44,00 \%$ & 28 & 78 & $52,00 \%$ & \\
\hline & 4 & 56 & $37,33 \%$ & 29 & 53 & $35,33 \%$ & \\
\hline & 5 & 111 & $74,00 \%$ & 37 & 50 & $33,33 \%$ & \\
\hline & 12 & 34 & $22,67 \%$ & 40 & 45 & $30,00 \%$ & \\
\hline Analisis, & 9 & 73 & $48,67 \%$ & 30 & 62 & $41,33 \%$ & \multirow{6}{*}{$\begin{array}{l}47,03 \\
\%\end{array}$} \\
\hline Evaluasi dan & 10 & 53 & $35,33 \%$ & 32 & 50 & $33,33 \%$ & \\
\hline Kreatif & 14 & 64 & $42,67 \%$ & 34 & 73 & $48,67 \%$ & \\
\hline \multirow[t]{3}{*}{$(\mathrm{C} 4, \mathrm{C} 5, \mathrm{C} 6)$} & 17 & 92 & $61,33 \%$ & 35 & 81 & $54,00 \%$ & \\
\hline & 18 & 101 & $67,33 \%$ & 38 & 66 & $44,00 \%$ & \\
\hline & 20 & 61 & $40,67 \%$ & & & & \\
\hline
\end{tabular}

Pengembangan Tes Diagnostik. Mata Pelajaran IPA SMP - 29 
Skor perolehan pada ranah kognitif $\mathrm{C} 1$ menunjukkan hasil skor $0=$ $2,00 \%$, skor $1=8,67 \%$, skor $2=12,67 \%$, skor $3=14,67$, skor $4=9,33 \%$, skor $5=13,33 \%$, skor $6=12,00 \%$, skor $7=11,33 \%$, skor $8=8,67 \%$, skor $9=5,33 \%$, skor $10=2,00 \%$, skor $11=0 \%$ dan skor $12=0 \%$.

Data tingkat pencapaian pada dimensi pengetahuan diambil dari uraian penjelasan pada jawaban responden. Dimensi pengetahuan meliputi dimensi faktual, dimensi konseptual, dimensi prosedural dan dimensi metakognitif. Skor uraian jawaban mempunyai tiga kategori yaitu jawaban dan alasan betul di beri skor 2, jawaban betul alasan salah diberi skor 1, jawaban dan alasan salah diberi skor 0 .

Tabel 7. Persentase Tingkat Pencapaian pada Dimensi Pengetahuan

\begin{tabular}{lclcc}
\hline $\begin{array}{c}\text { Dimensi } \\
\text { Pengetahuan }\end{array}$ & $\begin{array}{c}\text { Persentase } \\
\text { Pencapaian }\end{array}$ & $\begin{array}{c}\text { Dimensi } \\
\text { Pengetahuan }\end{array}$ & $\begin{array}{c}\text { Persentase } \\
\text { Pencapaian }\end{array}$ & $\begin{array}{c}\text { Rata-rata } \\
\text { Pencapaian }\end{array}$ \\
\hline Faktual & $53,87 \%$ & Prosedural & $49,87 \%$ & $51,23 \%$ \\
Konseptual & $51,40 \%$ & Metakognitf & $49,80 \%$ & \\
\hline
\end{tabular}

Rata-rata tingkat pencapaian pada dimensi pengetahuan adalah $51,23 \%$. Penguasaan tertinggi pada dimensi faktual 53,87\% dan penguasaan terendah pada dimensi metakognitif 49,80\%.

Karakteristik butir soal hasil pengembangan mempunyai spesifikasi tingkat kesukaran, daya beda, efektivitas pengecoh, validitas dan reliabilitas. Tingkat kesukaran dari 29 item soal terdapat 5 soal yang tergolong sukar karena mempunyai indeks di bawah 0,31 dan terdapat 24 item soal yang tergolong sedang, mempunyai indeks di atas atau sama dengan 0,31. Tingkat kesukaran butir soal hasil pengembangan rata-rata adalah 0,425 atau tergolong sedang karena berada pada rentang 0,31-0,70. Berdasarkan pendapat Wahidmurni (2010: 132), taraf kesukaran untuk tes diagnostik adalah sedang, maka tes diagnostik hasil pengembangan ini memenuhi syarat sebagai tes diagnostik.

Daya beda butir soal hasil pengembangan mempunyai rata-rata 0,415. Soal diterima tetapi perlu diperbaiki mempunyai daya beda 0,30-0,39 terdapat 3 soal. Ketiga soal tersebut direvisi pada option. Soal diterima baik 
sekali (excellent) mempunyai daya beda 0,40-1,00 terdapat 26 soal. Berdasarkan klasifikasi Wahidmurni, tes diagnostik hasil pengembangan ini tergolong baik sekali. Efektivitas pengecoh butir soal hasil pengembangan dari 29 soal mempunyai efektivitas di atas 5\%, dan ini sesuai pendapat Arikunto (2009: 220), distribusi pilihan jawaban (efektivitas distraktor), dapat berfungsi jika paling sedikit dipilih oleh $5 \%$ peserta tes.

Reliabilitas tes hasil pengembangan mempunyai koefisien reliabilitas sebesar 0,814 dengan demikian konstruk tes diagnostik yang dikembangkan adalah reliabel, ini menunjukkan bahwa tingkat keajegan atau kestabilan perangkat tes diagnostik yang dikembangkan jika diuji lagi pada responden yang sama pencapaian skor akan sama pada taraf $81 \%$. Berdasarkan tingkat keajegan, maka hasil pengembangan instrumen tes diagnostik ini dapat dibakukan.

Berdasarkan data statistik tes diagnostik yang dikembangkan, menunjukkan besarnya standard error of measurement (SEM) atau kesalahan baku pengukuran adalah 7,09. Dalam tabel Doppelt (Gronlund, 1990: 91) maka kesalahan baku dapat dibenarkan.

\section{Pembahasan Hasil Diagnostik}

Menurut hasil penelitian Saidah (2012), media tes diagnostik layak digunakan untuk mendiagnosis kesulitan belajar siswa berdasarkan ketuntasan indikator dan peta diagnostik kesulitan belajar. Hal ini tidak berbeda dengan hasil penelitian ini bahwa pengembangan tes diagnostik menunjukkan pada pencapaian hasil belajar berdasarkan SK, KD, indikator, ranah kognitif, dan dimensi pengetahuan, siswa masih kesulitan dalam menguasai materi pelajaran. Hasil analisis dari lembar jawaban pada uraian, siswa kurang mampu menyusun argumentasi pada setiap memberi jawaban soal, demikian juga pada uraian yang memerlukan deskripsi jawaban dalam bentuk angka. Soal-soal dalam bentuk gambar yang merupakan soal-soal pada dimensi pengetahuan faktual juga siswa mengalami kesulitan memberikan argumen. Sesuai dengan kesimpulan Purwati (2008), tes diagnostik sangat penting dilakukan oleh guru untuk mendiagnostik kemampuan siswa dan menentukan materi yang harus lebih ditekankan oleh guru dalam proses pembelajaran.

Pengembangan Tes Diagnostik, Mata Pelajaran IPA SMP - 31 Mujiman Hendri Wijaya, Suratno, Aminuddin HP 
Pencapaian Hasil Belajar Siswa Berdasarkan Ranah Kognitif

Hasil belajar siswa berdasarkan ranah kognitif menunjukkan bahwa tingkat pencapaian ranah C1 justru paling rendah, artinya siswa kurang menguasai pengetahuan tentang fakta dan konsep. Soal-soal yang mengukur ranah C1 disajikan dalam bentuk gambar yaitu soal yang berhubungan dengan fakta dan disajikan dalam bentuk data untuk soal-soal konseptual atau ingatan. Hasil penelitian ini mengungkapkan bahwa siswa kurang melakukan kegiatan proses dalam pembelajaran dan kurang mendapat pengalaman langsung sehingga siswa tidak mampu mengingat materi pelajaran yang sifatnya faktual atau konseptual dalam kehidupan sehari-hari.

Analisis pada aspek proses kognitif C2, C3, C4,5,6 menunjukkan masih di bawah batas pencapaian minimal, artinya siswa masih mengalami kesulitan dalam menuntaskan materi pelajaran. Bentuk butir soal yang dikembangkan pada aspek ingatan berupa mengingat nama dan bentuk gambar, soal-soal yang mengukur kemampuan pemahaman berbentuk konsep. Soal-soal yang mengukur kemampuan penerapan berbentuk langkah kerja dan aplikasi dalam kehidupan sehari-hari, sedangkan soal yang mengukur kemampuan analisis, evaluasi dan kreativitas adalah menyimpulkan dan membedakan.

Pencapaian Hasil Belajar Siswa Berdasarkan pada Dimensi Pengetahuan

Hasil analisis pencapaian hasil belajar pada dimensi pengetahuan ditunjukkan pada Tabel 7. Soal-soal yang berhubungan dengan kemampuan faktual disajikan dalam bentuk gambar. Kemampuan faktual lebih mengutamakan kemampuan panca indra, jika siswa tidak melakukan keterampilan proses dan melakukan pengalaman langsung pada materi pelajaran kemungkinan besar siswa mudah lupa dan sulit untuk mendeskripsikan pengalamannya. Analisis lembar jawaban menunjukkan bahwa siswa masih mengalami kesulitan untuk mengutarakan atau memberi uraian pada setiap soal.

Berdasarkan batas pencapaian 65\%, siswa masih mengalami kesulitan belajar dalam dimensi pengetahuan. Siswa masih lemah dalam penguasaan keterampilan prasyarat bahasa dan matematika, hal ini ditunjukkan oleh 
deskripsi jawaban siswa. Siswa kurang mampu menyusun kalimat dan menggunakan operasi matematika. Hasil penelitian ini diperkuat oleh hasil penelitian tentang tes diagnostik Chakim (2005), siswa memiliki kelemahan, prasyarat pengetahuan, miskonsepsi, pengetahuan matematis, dan pengetahuan bahasa.

\section{Hasil Pengembangan Tes Diagnostik}

Pengembangan tes diagnostik dalam penelitian ini menghasilkan 29 butir soal yang memenuhi syarat standar setelah dilakukan uji empiris. Dari 29 butir soal terdiri 11 soal mengukur aspek kognitif ranah C1, 4 soal ranah C2, 7 soal ranah C3, dan 7 soal ranah C4,5,6. Soal-soal yang mengukur dimensi pengetahuan terdiri dari 8 soal dimensi faktual, 7 soal dimensi konseptual, 8 soal dimensi prosedural dan 6 soal dimensi metakognitif.

\section{Prosedur Pelaksanaan Tes Diagnostik Hasil Pengembangan}

Siswa yang diindikasikan mengalami kesulitan belajar ini dapat diketahui dari capaian hasil belajar melalui ulangan formatif dan ulangan sumatif. Secara jelas prosedur pelaksanaan tes diagnostik dapat dilihat pada Gambar 1.

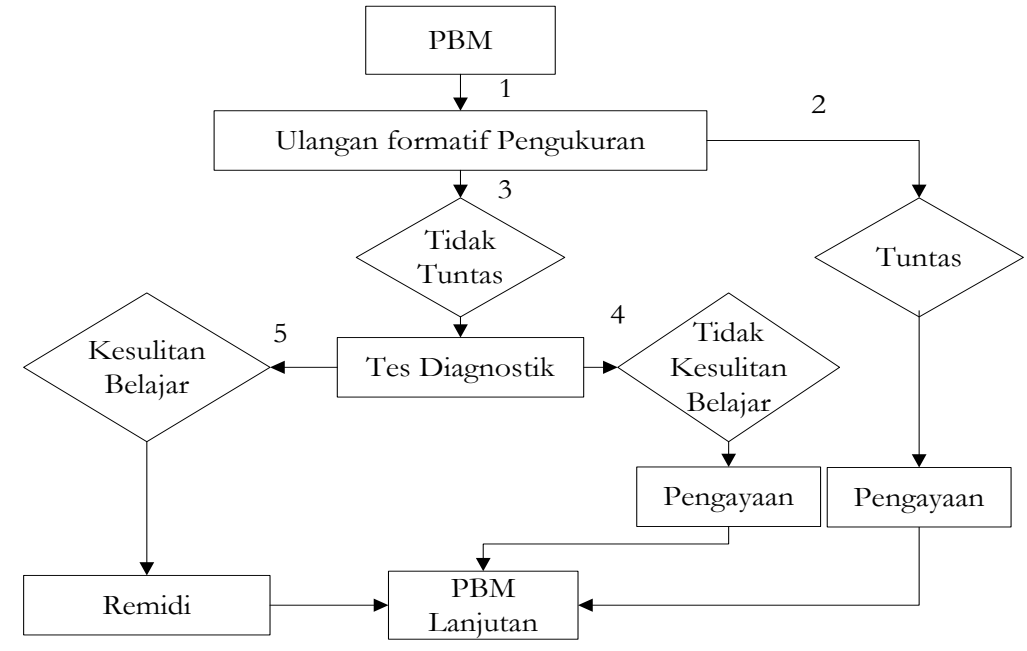

Gambar 1. Bagan Prosedur Pelaksanaan Tes Diagnostik Hasil Pengembangan

Pengembangan Tes Diagnostik, Mata Pelajaran IPA SMP - 33 Mujiman Hendri Wijaya, Suratno, Aminuddin HP 
Proses belajar mengajar (PBM) yang telah menyelesaikan satu kompetensi dasar (KD) diakhiri dengan tes formatif (prosedur 1). Hasil dari tes formatif akan menunjukkan siswa telah tuntas menyelesaikan materi pelajaran dan siswa belum tuntas menyelesaikan materi pelajaran. Siswa yang telah tuntas menyelesaikan materi pelajaran (prosedur 2) diberi bahan pengayaan pada kelas khusus sebelum mengikuti PBM lanjutan. Siswa yang belum tuntas menyelesaikan materi pelajaran (prosedur 3) diberikan tes diagnostik. Hasil tes diagnostik akan menunjukkan ada kelompok siswa yang mengalami kesulitan belajar dan kelompok siswa yang tidak mengalami kesulitan belajar. Jika dari hasil diagnostik menunjukkan ada kelompok siswa yang tidak mengalami kesulitan belajar (prosedur 4), maka kelompok siswa ini harus diberi pengayaan pada kelas biasa sebelum mengikuti PBM lanjutan. Jika dari hasil diagnostik menunjukkan ada kelompok siswa yang mengalami kesulitan belajar (prosedur 5), maka kelompok siswa ini harus diberi remidi pada kelas remidi sebelum mengikuti PBM lanjutan.

\section{Menentukan Siswa yang Mengalami Kesulitan Belajar}

Tes diagnostik yang dikembangkan ini digunakan untuk mengetahui siswa yang mengalami kesulitan dalam mengikuti proses belajar. Siswa yang diperkirakan mengalami kesulitan dalam proses belajar dapat diketahui dengan melihat skor hasil tes diagnostik dengan membandingkan batas minimal penguasaan yang ditetapkan. Tes dignostik mempunyai tingkat kesukaran sedang sehingga batas minimal penguasaan belajar secara umum untuk tes diagnostik adalah 65\% atau skor 65 pada rentang skor 0-100. Siswa yang diperkirakan mengalami kesulitan belajar yaitu siswa yang mempunyai skor di bawah batas minimal penguasaan $65+0,25 \times$ standar deviasi atau jika masih menggunakan skor mentah dengan rumus mean + $0,25 \times$ standar deviasi.

\section{Simpulan dan Saran}

Hasil penelitian pengembangan tes diagnostik ini dapat disimpulkan (1) diperoleh instrumen tes diagnostik standar pada mata pelajaran IPA 
Biologi di SMP Kabupaten Barito Kuala, (2) desiminasi instrumen tes diagnostik hasil pengembangan untuk mengungkap kesulitan belajar siswa SMP pada materi pelajaran IPA Biologi berupa buku.

Berdasarkan hasil penelitian dan kesimpulan, dapat dikemukakan beberapa saran untuk penelitian lanjutan adalah (1) perlu adanya pengembangan tes diagnostik lebih lanjut yang dapat mengungkap penyebab kesulitan belajar siswa, (2) pengembangan tes diagnostik akan lebih praktis dan ekonomis jika didesain secara komputerisasi.

\section{Daftar Pustaka}

Arikunto, Suharsimi. (2009). Dasar-dasar Evaluasi Pendidikan. Bumi Aksara. Jakarta.

BSNP. (2010). Laporan Hasil Ujian Nasional Tabun Pelajaran 2009/2010 SMP/ MTs. Pusat Penilaian Pendidikan Badan Penelitian dan Pe-ngembangan Kementerian Pendidikan.

BSNP. (2012). Prosedur Operasional Standar Ujian Nasional Sekolah Menengah Pertama, Madrasah Tsanawiyah, Sekolah Menengah Luar Biasa, sekolah Menengah Atas, Madrasah Aliyah, Sekolah Menengah Atas Luar Biasa, dan Sekolah Menengah Kejuruan Tabun 2011/2012. Mendikdasmen. Jakarta Selatan.

Chakim, Aziz. (2005). Penyusunan Tes Diagnostik Sains (Fisika) Pokok Bahasan Tekanan Untuk Siswa SMP Kelas I Semester II Se-Kota Semarang Tabun Pelajaran 2003/2004. Semarang.

Depdiknas. (2007). Pedoman Pengembangan Tes Diagnostik Mata Pelajaran IPA $S M P / M T s / 1$. Departemen Pendidikan Nasional Direktorat Jenderal Manajemen Pendidikan Dasar dan Menengah Direktorat Pembinaan Sekolah Menengah Pertama. Jakarta.

Depdiknas. (2010a). Buku Saku Kurikulum Tingkat Satuan Pendidikan (KTSP) Sekolah Menengah Pertama. Dinas Pendidikan Provinsi Kalimantan Selatan. Banjarmasin.

Depdiknas. (2010b). Panduan Pengembangan Pembelajaran IPA Terpadu Sekolah Menengah Pertama/Madrasah Tsanawiyah (SMP/MTs). Pusat Kuriku-lum, Balitbang. Jakarta Pusat. 
Jurnal Penelitian dan Evaluasi Pendidikan

Gronlund, Norman E \& Robert L.Linn. 1990. Measurement and Evaluation in Teaching. 6th Edition. University of Illinonis, University of Coro-rado. New York.

Ghozali, Imam. (2007). Aplikasi multivariate dengan program SPSS. Badan Penerbit Universitas Diponegoro. Semarang.

Kemendiknas. (2010). Renstra Depdiknas 2010-2011. Pusat Kurikulum, Balitbang. Jakarta Pusat.

Mukhan, Suhadi. (2011). Pedoman Pengembangan Tes Diagnostik Mata Pelajaran IPA (Sains) di SMP.Departemen Pendidikan Nasional Direktorat Jenderal Manajemen Pendidikan Dasar dan Menengah. Direktorat Pembinaan Sekolah Menengah Pertama. Jakarta.

Mulyadi. (2008). Diagnostik Kesulitan Belajar dan Bimbingan terhadap Kesulitan Belajar Khusus. Nuha Litera. Malang.

Purwati, Ani. (2008). Tes Diagnostik dan Remedial Teaching untuk Meningkatkan Hasil Belajar Matematika Siswa Kelas IV Jakarta Timur. Jurnal Lingkar Mutu Pendidikan.Vol I (1): 77

Saidah, Khois Nafiatus \& Rinaningsih. (2012). The Development of diagnostic Test Used PHP-Mysql in Subject Reaction Rate for Senior High School $11^{\text {th }}$ Grade. Unesa Journal of Chemical Education. Vol I (1):145-153

Styosari, Punaji. (2012). Metode Penelitian Pendidikan dan Pengembangan. Kencana Prenada Media Group. Rawamangun Jakarta.

Wahidmurni, Mustikawan, A., \& Ridho, A. (2010). Evaluasi Pembelajaran Kompetensi dan Praktik. Nuha Litera. Malang.

Wibowo, Sudirgo. (1977). Penyusunan Test Kemampuan Diferensiil Sebagai Test untuk Seleksi Calon Mahasiswa. Gadjah Mada University Press. Fakultas Psikologi, Universitas Indonesia.

Wright, R.J. (2008). Educational Assessment, Tests and Measurements in the Age of Accountability. Sage Publications. Los Angeles, London, New Delhi, Singapore.

36 - Jurnal Penelitian dan Evaluasi Pendidikan Tahun 17, Nomor 1, 2013 